MATEC Web of Conferences 19, 01015 (2014)

DOI: $10.1051 /$ matecconf/ 20141901015

(C) Owned by the authors, published by EDP Sciences, 2014

\title{
Low-temperature conversion of low-grade organic raw, part 2 (economic aspects)
}

\author{
Alexander S. Zavorin, Roman B. Tabakaev, Pavel Y. Novoseltsev, and Alexander V. Astafev \\ National Research Tomsk Polytechnic University, 634050 Tomsk, Russia
}

\begin{abstract}
Algorithm for estimating the efficiency of investment in innovative energy technologies has been used as a method of research. Two scripts of the project development (optimistic and pessimistic) were considered. Cost-effectiveness of replacing diesel power plants on the conversion units was determined.
\end{abstract}

\section{Method of research}

Algorithm from work [1], devoted to the creation of evaluation tools of the efficiency of investment in innovative energy technologies [2-4] and based on a comprehensive assessment of energy consumption, energy resources, new technology and the environment is selected as a method of analysis of the efficiency of introduction of innovative energy technologies based on the units of intracyclic conversion (the individual heat supply unit, individual heat and power supply unit and unit of solid fuels gasification - gasifier).

Primarily fuel requirement is determined and capabilities of the extraction of energy resources are analyzed for evaluate of energy consumption and energy resources of the distant settlements. Previous technical and economic evaluation, which implies evaluation of the environmental situation in the region and the forecast of technical and economic parameters of local energy resources, is made for this analysis. Inexpediency of the investment of selected energy technologies is concluded in the case of negative results of technical and economic evaluation. Script of the assimilation of innovative energy technologies is formed in the case of positive results. Then, decrease or increase of harmful emissions by using new technologies is concluded based on the evaluation of environmental situation. In case of exceeding of the previous parameters on harmful emissions is made conclusion about undesirability of use these technologies and their introduction is deflected. The evaluation of the overall efficiency and scales of replicating these technologies is made with reducing emissions and on the basis of formed scripts assimilation of innovative energy technologies. Technologies are considered inefficient in the case of negative results of this evaluation. Analysis of commercial and budgetary efficiency, prevented environmental damage is made in the case of positive results. Evaluation of commercial efficiency is included the identification of the risks of assimilation new technologies, the sensitivity analysis, the definition of the borders of break-even, the definition of the expected integral effect to assimilation of technology in borders of break-even. Decision about expediency of the project is adopted in the case of positive integral effect. Evaluation of commercial efficiency including possible third-party investors is made in the case of negative integral effect. The project is considered inexpedient if the expected integral effect remains negative even taking into account investors. 


\section{Results and discussion}

Costs for units (Table 1) are determined of the capital costs and the annual costs on maintaining of operating condition. Capital (nonrecurring closing) costs for units are determined by the size of wage costs, material costs, overhead costs and equipment costs. Operating costs are determined by the size of the fuel costs, maintenance, water costs and amortization. The purpose of the work is experimental research of features of water droplets, kerosene and ethanol deformation in the air.

Table 1. Costs for the units, thousandrubles.

\begin{tabular}{|l|c|c|c|c|c|c|c|c|c|}
\hline \multirow{2}{*}{$\begin{array}{c}\text { Kind of } \\
\text { costs }\end{array}$} & \multicolumn{2}{|c|}{ Individual heat supply unit } & \multicolumn{3}{|c|}{ Individual heat and power } & \multicolumn{3}{c|}{ Gasifier } \\
\cline { 2 - 11 } & $\mathbf{1 0 0} \mathbf{k W}$ & $\mathbf{5 5} \mathbf{k W}$ & $\mathbf{4} \mathbf{k W}$ & $\mathbf{1 0 0} \mathbf{k W}$ & $\mathbf{5 0} \mathbf{k W}$ & $\mathbf{3} \mathbf{k W}$ & $\mathbf{1 0 0} \mathbf{k W}$ & $\mathbf{5 0} \mathbf{k W}$ & $\mathbf{3} \mathbf{k W}$ \\
\hline Capital & 334 & 205 & 28 & 252 & 178 & 25 & 266 & 177 & 25 \\
\hline Operating & 42 & 32 & 19 & 47 & 35 & 24 & 52 & 45 & 33 \\
\hline
\end{tabular}

Such low operating costs, primarily related to the lack of a fuel component, upon condition of administrative and legal assistance in realization of the program of substitution diesel power plants (DPP) under units. In the case of fuel costs, the appropriate calculation of parameters is given below (Table 5-7). Annual fuel costs for DPP with power $100 \mathrm{~kW}$ (according to [5]), in the order of 240 thousand rubles. From this it follows that the savings in operating costs are combined at a minimum of 188-198 thousand rubles when working one plant with a power of $100 \mathrm{~kW}$ at the appropriate capital costs 252-334 thousands rubles. Parameters of investment performance (Table 2) in reliance on $100 \mathrm{~kW}$ of installed power are determined on the basis of cost results. Here, net present value $(N P V)$ is defined by the difference between the cost savings $\left(D_{t}\right)$ when introducing the units considering the discount rate $(\mathrm{i}=10 \%)$ and the initial investment $\left(I_{t}\right)$ in production of units:

$$
N P V=\sum_{t=1}^{3} \frac{D_{t}}{(1+i)^{2}}-\sum_{t=1}^{3} I_{t}
$$

Table 2. Parameters of investment performance, thousand rubles.

\begin{tabular}{|c|c|c|c|c|c|c|c|}
\hline \multirow{2}{*}{ Parameters } & \multirow{2}{*}{\multicolumn{2}{|c|}{ Symbol }} & Assembly, year & \multicolumn{4}{|c|}{ Operation, year } \\
\hline & & & 0 & 1 & 2 & 3 & 5 \\
\hline \multirow{3}{*}{ Investment } & \multirow{3}{*}{$I_{t}$} & Individual heat supply unit & 334 & - & - & - & - \\
\hline & & Individual heat and power supply & 252 & - & - & - & - \\
\hline & & Gasifier & 266 & - & - & - & - \\
\hline \multirow{3}{*}{ Cost savings } & \multirow{3}{*}{$D_{t}$} & Individual heat supply unit & - & -136 & 62 & 260 & 656 \\
\hline & & Individual heat and power supply & - & -59 & 134 & 327 & 738 \\
\hline & & Gasifier & - & -78 & 110 & 298 & 724 \\
\hline \multirow{3}{*}{$\begin{array}{l}\text { Net present } \\
\text { value }(N P V)\end{array}$} & \multirow{3}{*}{$N P V$} & Individual heat supply unit & -334 & -124 & 51 & 195 & 407 \\
\hline & & Individual heat and power supply & -252 & -54 & 111 & 246 & 458 \\
\hline & & Gasifier & -266 & -71 & 91 & 224 & 450 \\
\hline
\end{tabular}

$N P V$ calculated by (1) shows that the costs of completely pays for itself and savings starts during the second year of operation.Presented above savings is an indicator of the budget efficiency on condition of the funding of developed project from local budget. This is accompanied by savings in operating costs associated with the generation of electric energy and the substitution of diesel power plants under units. For 5 years, the total savings $(N P V)$ in reliance on $100 \mathrm{~kW}$ of installed power will range from 509 to 878 thousand rubles with the average savings of 85-146 thousand rubles depending on the type of units. Social efficiency of the introduction of units achieved by reducing of the cost price of manufactured products - heat and electric energy and as a result reducing of the selling price. 
Speaking about the potential efficiency of the project to substitution of the entire park DPP under units in Tomsk region, it can be stated that savings of operating costs in reliance on $50 \mathrm{MW}$ of total installed power can reach the level of 97 million rubles annually (Table 3).

Table 3. Potential efficiency of the project, thousand rubles.

\begin{tabular}{|l|c|c|c|c|}
\hline \multirow{2}{*}{ Parameter } & \multicolumn{3}{|c|}{ Installation } \\
\cline { 2 - 5 } & DPP & $\begin{array}{c}\text { Individual heat } \\
\text { supply unit }\end{array}$ & $\begin{array}{c}\text { Individual heat and } \\
\text { power supply }\end{array}$ & Gasifier \\
\hline $\begin{array}{l}\text { Operating costs in reliance on 100 kW } \\
\text { of power }\end{array}$ & 240 & 42 & 47 & 52 \\
\hline $\begin{array}{l}\text { Operating costs in reliance on 50 MW } \\
\text { of power }\end{array}$ & 120000 & 21000 & 23500 & 26000 \\
\hline $\begin{array}{l}\text { Savings of operating costs inreliance } \\
\text { on 50 MW of power }\end{array}$ & - & 99000 & 96500 & 94000 \\
\hline
\end{tabular}

Operating costs for DPP (Table 3) are given based on the cost of diesel fuel as of 2002 [1]. Accordingly it is possible count on fold increase of the savings of operating costs during the transition to the production of electric energy with help of units in reliance on $50 \mathrm{MW}$ of total installed power for covering of the needs of isolated areas in Tomsk region.

Evaluation of prevented environmental damage from air pollution by emissions makes according to the chosen method of analysis of the efficiency of introduction innovative energy technologies [6]. Thus, the relative detriment to atmospheric air, which is placed by ejection of the unit of reduced mass pollutants, is 5510.6 rubles/ton, reduced mass of pollutant emissions from stationary sources of emissions not received into the atmospheric air -6.33 ton, and prevented environmental damage from air pollutions by emissions is evaluated at 38.37 thousand rubles.

Evaluation of commercial efficiency involves the identification of technical, financial and economic, environmental and social risks, which allows to determine the probability of the risk as a whole. Technical risks are determined by the dependence of the use of technology from quality of energy resources (low-grade fuel), reliability and safety of the introduced technology of low temperature intracyclic conversion, the actual amounts of energy and resource conservation. Financial and economic risks are determined by instability of the volume of demand, change in the taxation system, change of penalties on environmental emissions, rising of the cost of used low-grade energy resources. Environmental risks are determined by the magnitude of environmental pollution during operation of units, as well as the possible consequences of crashes involving harmful emissions. Social risks are determined by the possible rise of tariffs on manufactured products, the lack of subsidies from the state budget. Definition of all these risks has predicted the magnitude of the overall risk (Table 4) for introduction of units.

Table 4. Predicted magnitude of the overall risk.

\begin{tabular}{|l|l|}
\hline Designation of risk & Magnitude of risk \\
\hline Technical & 0.07 \\
\hline Financial and economic & 0.08 \\
\hline Environmental & 0.12 \\
\hline Social & 0.06 \\
\hline Overall & 0.33 \\
\hline
\end{tabular}

Results of calculation are showed that probability of occurrence of the overall risk is below average and closer to the criterion "sooner will not occur". The highest magnitude poses environmental risks associated with importance of the preventing of occurrence such development. Technical risks are primarily caused by reliability and safety of introduced technology. Financial and economic risks are mainly depended by the cost of used raw materials, and social risks are entirely depended on the policy pursued by the local authorities. 


\section{MATEC Web of Conferences}

Analysis of the sensitivity of project to substitution of the active park DPP under units is performed for optimistic and pessimistic scripts associated with changes in the cost of low-grade fuel in range of 0-300 rubles/ton, and norm of discount (rate of return) of 10-25\% in the case of the attracting of private investors. Thus, the optimistic and pessimistic scripts are characterized by the following parameters (Table 5).

Table 5. Predicted magnitude of the overall risk.

\begin{tabular}{|c|c|c|}
\hline \multirow{2}{*}{ Script } & \multicolumn{2}{|c|}{ Prospective range of change parameters } \\
\cline { 2 - 3 } & Fuel cost, rules ton & Norm of discount, $\%$ \\
\hline Optimistic & 0 & 10 \\
\hline Pessimistic & 300 & 25 \\
\hline
\end{tabular}

Magnitude of the net present value $(N P V)$, calculated by two scenarios is used on sensitivity analysis. NPV for optimistic script is values calculated according to data of Table 2. NPV for pessimistic script are given in Table 7 (values are given in reliance on $100 \mathrm{~kW}$ of installed power in 5 years).

Table 6. NPV for optimistic and pessimistic scripts.

\begin{tabular}{|c|c|c|c|}
\hline \multirow{2}{*}{ Script } & \multicolumn{3}{|c|}{ NPV, thousand rubles } \\
\cline { 2 - 4 } & Individual heat supply unit & Individual heat and power supply & Gasifier \\
\hline Optimistic & 509 & 878 & 787 \\
\hline Pessimistic & 68 & 353 & 283 \\
\hline
\end{tabular}

Savings of fuel component is 19-49 thousand rubles in monetary terms in second year of operation according to calculations by the pessimistic script depending on the type of installation with power of $100 \mathrm{~kW}$. Calculation of the potential efficiency of the project produced of similar calculations, the values of which are given in Table 3 by the pessimistic script in reliance on $50 \mathrm{MW}$ of total installed power in the form of the savings of operating costs on average for 1 year. These savings is 6.8 million rublesin year for the individual heat supply unit, 35.3 - for the individual heat and power supply and 28.3 - for the gasifier. Evaluation of the efficiency of project, taking into account the existing uncertainty in the form of two scripts of the development, is carried out by determining of the expected integral effect $\left(\ni_{e x}\right)$, which depends on the maximal $\left(\ni_{\max }\right)$ and minimum $\left(\ni_{\min }\right)$ integral effects $(N P V)$ on considered scripts, given of normative $(\lambda)$, which reflects the preferences of respective economic entity in the conditions of uncertainty:

$$
\ni_{e x}=\ni_{\max } \cdot \lambda+(1-\lambda) \cdot \ni_{\min }
$$

The values of the expected integral effect from project realization to substitution of the entire park DPP under units in Tomsk region in reliance on the 5 years, taking into account uncertainty are given in Table 7.

Table 7. Values of the expected integral effect in 5 years.

\begin{tabular}{|l|c|}
\hline \multicolumn{1}{|c|}{ Type of installation } & Expected integral effect, million rubles \\
\hline Individual heat supply unit & 100.15 \\
\hline Individual heat and power supply & 255.25 \\
\hline Gasifier & 217.10 \\
\hline
\end{tabular}

Thus, realization of project to substitution of the entire park DPP under units in conditions of uncertainty, based on the results of Table 7, is appeared economically viable in terms of attracting investment from budgets of various levels and private equity. 


\section{Conclusions}

1. The capital costs on the production of units exceed cost of the existing DPP, but low operating costs, determined by fuel cost, are leaded to a rapid payback.

2. The budget efficiency of the project to substitution of the entire park DPP under units is determined by savings on fuel component in the process of generating electric energy, which can attain the level of 97 million rubles in year.

3. The sensitivity of the project to change of external factors in the form of optimistic and pessimistic scripts, depending on the fuel cost and the discount rate, is changed in the range of 2.57.5 times, while showing a positive effect.

4. The expected integral effect of the realization of project to substitution of the entire park DPP under units in Tomsk region for 5 years is founded at the level of 100-255 million rubles, which is evidence of the economic feasibility of replicating units.

The reported study was partially supported by the Ministry of education and science of The Russian Federation (Government Order No. 13.948.2014/K).

\section{References}

1. M. V. Zubova, Candidate's Dissertation in Technical Sciences (SFU, Krasnoyarsk, 2007) [in Russian]

2. A.V. Kazakov, A.S. Zavorin, P. Y. Novoseltsev, R. B. Tabakaev, Bulletin of the Tomsk Polytechnic University 324, 54 (2014) [in Russian]

3. A. S. Zavorin, A.V. Kazakov, R. B. Tabakaev, RF Patent No. 2498 166, Byull. Izobret., No. 31 (2013)

4. A. S. Zavorin, A.A. Makeev, A. V. Kazakov, S.V. Podorov, RF Patent No 2337 941, Byull. Izobret., No. 31 (2008).

5. M. N. Sergeev, Proceedings of III National Conference "Energy and Energy Security of Russian Regions", 2002, p. 30-38 [in Russian]

6. V. I.Danilov-Daniliyan, Temporary method for determination of avoided environmental damage (Russian Federation State Committee for Environmental Protection, Moscow, 1999) [in Russian] 